\title{
Xylem sap analysis reveals new facts of salt tolerance in rice genotypes
}

\author{
Parto Roshandel*
}

Department of Biology and Enviromental Science, University of Sussex, UK. Present address: Department of Biology, Faculty of Sciences, Shahrekord University, P.O.Box 115, Iran. *Corresponding author: p_roshandel@yahoo.com

Received: 18 July 2007; Returned for revision: 08 October 2007; Accepted: 18 December 2007

Salinity damage in rice and other salt-sensitive species is due to excessive transport of $\mathrm{NaCl}$ through the root system to the leaves and consequently low salt transport to the shoot can be a major trait determining salt resistance. Since the rapid uptake of sodium ions is such a crucial part of the response of rice to salinity, physiological experiments were carried out to compare bypass flow in two genotypes of rice (IR4630 and IR15324) differing in salt tolerance, because it has been suggested that an apoplastic pathway, bypass flow, is a major contributory pathway for $\mathrm{Na}^{+}$entrance into rice plants. Experiments on the youngest fully expanded photosynthetic leaf (the third from the base), using PTS as a tracer for apoplastic movement and Philaenus spumarius (a xylem-feeding insect) as a means to sample the xylem sap, did not demonstrate any apparent difference in bypass flow between the two lines. The similarity of $\mathrm{Na}^{+}$concentration in the xylem sap of both genotypes paralleled the results of PTS (a fluorescent dye used as an apoplastic tracer for the transpiration stream) measurements. Despite the similarity of $\mathrm{Na}^{+}$concentration in the xylem sap of the third leaves, the $\mathrm{Na}^{+}$concentration in the bulk of these leaves of IR15324 plants (the sensitive line) was about twice that of IR4630 (the tolerant line). Measurements of transpiration over $8 \mathrm{~d}$ of salinisation showed the similarity of rates in both lines providing evidence that the greater accumulation of $\mathrm{NaCl}$ in IR15324 than in IR4630 plants was unlikely to be due to a difference in the delivery of salt to the leaves by an apoplastic route. Results of the current work suggest that the difference in salt tolerance might be a consequence of damage to leaves 1 and 2 of IR15324 that allowed $\mathrm{Na}^{+}$to leak into the phloem - and consequently move to leaf 3.

Key words: bypass flow, $\mathrm{Na}^{+}$transport, Oryza sativa, Philaenus spumarius, salt stress, xylem concentration

A análise da seiva do xilema revela novos fatos sobre a tolerância a sais em genótipos de arroz: Danos por salinidade em arroz e em outras espécies sensíveis ao estresse salino são devidos ao transporte excessivo de $\mathrm{NaCl}$, desde o sistema radicular até as folhas; assim, baixo transporte de sais para os ramos pode ser uma característica importante na determinação da resistência salina. Uma vez que a absorção rápida dos íons sódio é uma parte crucial da resposta do arroz à salinidade, conduziram-se experimentos para comparar-se o fluxo (apoplástico) pelo desvio (bypass flow) de dois genótipos de arroz (IR4630 e IR15324) diferindo na tolerância salina, visto ser esse fluxo uma das principais rotas pelas quais o $\mathrm{Na}^{+}$entra nas raízes de arroz. Experimentos com as folhas mais jovens completamente expandidas (terceira a partir do ápice), usando-se o PTS (um corante fluorescente como um traçador apoplástico para a corrente transpiratória) e o inseto Philaenus spumarius para amostragens da seiva do xilema, não demonstraram qualquer diferença aparente no chamado fluxo pelo desvio entre os dois genótipos. A similaridade da concentração de $\mathrm{Na}^{+}$na seiva do xilema de ambos genótipos foi respaldada pelos resultados de medições de PTS. Apesar dessa similaridade, a concentração de $\mathrm{Na}^{+}$nos tecidos da terceira folha, como um todo, em IR15324 (linhagem sensível) foi cerca de duas vezes maior que em IR4630 (linhagem tolerante). As taxas de transpiração ao longo $8 \mathrm{~d}$ de salinização foram similares entre os dois genótipos, evidenciando que o maior acúmulo de $\mathrm{NaCl}$ nas plantas de IR15324 não foi, provavelmente, devido a diferenças de 
suprimento de sal às folhas, via uma rota apoplástica. Os resultados deste trabalho sugerem que a diferença na tolerância salina pode ser uma conseqüência de danos às folhas 1 e 2 em IR15234, que permitiram maior vazamento de $\mathrm{Na}^{+}$no floema - e conseqüentemente transporte de $\mathrm{Na}^{+}$para a folha 3.

Palavras-chave: concentração do xilema, estresse salino, fluxo pelo desvio, Oryza sativa, Philaenus spumarius, transporte de $\mathrm{Na}^{+}$

\section{INTRODUCTION}

Soil salinity represents an increasing threat to agricultural production throughout the world, and millions of hectares of agricultural land show decreased yields because of high salinity (Flowers and Yeo, 1995). Some crops are more tolerant of salt than others, and can maintain their yield under some salinity. These species utilise a complex set of traits that involve morphological and developmental as well as physiological and biochemical processes (Hasegawa et al., 2000), including salt exclusion in the root (Munns, 2002), sequestration in the leaf cell vacuoles (Blumwald et al., 2000; Munns et al., 2002) and, controversially, ion retranslocation from the leaves (Lessani and Marschner, 1978; Berthomieu and Conejero, 2003). An important feature of salt stress is $\mathrm{Na}^{+}$ invasion of plant tissue and salt tolerance of many plants is conferred by the restriction of $\mathrm{Na}^{+}$entrance into plants. Although $\mathrm{Na}^{+}$readily enters plant cells, the transporters involved are difficult to identify (Amtmann and Sanders, 1999; Maathuis and Sanders, 2001; Apse and Blumwald, 2007). There is evidence to suggest that $\mathrm{Na}^{+}$enters plant cells through the high-affinity $\mathrm{K}^{+}$transporter HKTs (Maser et al., 2002; Horie et al., 2007), inward-rectifying $\mathrm{K}^{+}$channels, low-affinity cation transporter (LCT1) and voltage-independent channels (VICs) (Amtmann and Sanders, 1999; Tester and Davenport, 2003; Apse and Blumwald, 2007). Besides passing through transporters, there is a quite separate possibility that leads to the passage of salts from roots to leaves and allows its accumulation to toxic levels, namely, transpirational bypass flow. Transpirational bypass flow is of major importance in the uptake of sodium in rice (Yeo et al., 1987; Yeo, 1992; Yadav et al., 1996). Bypass flow is, as defined by Yeo et al. (1987), "leakage along a direct apoplastic contact from the external medium to the xylem in regions of the root where the endodermis has not yet differentiated or has been disrupted by development of lateral roots". So, bypass flow is assumed to be a result of root morphology and anatomy and depends on the developmental pathway of the root system. Because of the importance of transpirational bypass flow to rice, it might be hypothesised that differences in salt tolerance between rice genotypes reflect differences in this trait. In other words, rice lines with lower transpiration rates and/ or lower bypass flow may accumulate lower concentrations of salt and therefore be more tolerant than lines with higher bypass flow/transpiration. Therefore, to test this hypothesis two rice genotypes (IR4630 and IR15324) were compared and in order to look at the xylem sap contents, a non-destructive method for sap collection using Philaenus spumarius (Malone et al., 1999, 2002) was applied together with PTS (trisodium, 3-hydroxy5,8,10-pyrene trisulphonic acid, tradename 'Pyranin', Bayer), a non-phytotoxic, water-soluble, fluorescent dye employed as an apoplastic tracer for the transpiration stream. The xylem sap of transpiring plants is believed to consist of a dilute solution of mineral ions, and organic and amino acids, together with trace compounds such as abscisic acid (Malone et al., 2002). However, this is difficult to determine accurately because pure xylem sap cannot be easily obtained. It is especially difficult to obtain xylem sap from plants that are transpiring, because in these, the sap is held under tension. Studies of xylem transport have almost all used indirect methods to obtain xylem sap, but these methods are destructive and cannot be used for analysis of nutrient dynamics within the shoots; additionally the solute composition of fluids extracted by these methods does not necessarily match that of the transpiration stream (Malone et al., 1999; Malone et al., 2002), because the sap that is expressed from excised plant materials is probably contaminated due to dilution from cut cells during collection (Malone et al., 1999). Novel approaches for the extraction of xylem sap from intact transpiring plants, using xylem-feeding insects, have been developed (Malone et al., 1999). Philaenus spumarius (Cercopidae) is one of a group of 
insects more commonly known as spittlebugs: it is highly polyphagous and able to feed on over 500 different host plants (Malone et al., 1999). In addition, it feeds from mature xylem at the full hydraulic tension of the transpiration stream (Malone et al., 1999). This insect has been used to study $\mathrm{Na}^{+}$exclusion from the shoot xylem of certain wheat and rice varieties (Watson et al., 2001; Gong et al., 2006). In addition, the meadow spittlebug has been used in combination with ion chromatography (IC) for rapid non-destructive analysis of all the macronutrient ions in the xylem of intact, transpiring plants of tomato, broad bean and pepper (Malone et al., 2002).

In the current work, P. spumarius was used to make direct determinations of PTS and cation levels, with the specific aim of comparing $\mathrm{Na}^{+}$and $\mathrm{K}^{+}$concentrations, in the xylem sap of intact transpiring plants of two rice genotypes, IR4630 and IR15324, with differing tolerance to salinity: IR4630 being more tolerant than IR15324.

\section{MATERIAL AND METHODS}

Seeds of two rice (Oryza sativa L.) genotypes (IR4630 and IR15324) were obtained from the International Rice Research Institute, Manila, Philippines. Seeds were soaked for $24 \mathrm{~h}$ in distilled water and transferred to a growth cabinet where they were allowed to germinate on the surface of nylon mesh placed over the nutrient solution of Yoshida et al. (1976), but modified by halving the phosphate concentration (earlier experiments with full-strength concentration of phosphate exhibited phosphate toxicity in the presence of external $\mathrm{NaCl}$ ). In addition, $\mathrm{NaH}_{2} \mathrm{PO}_{4} \cdot 2 \mathrm{H}_{2} \mathrm{O}$ as the phosphate supplement in the original protocol was replaced for $\mathrm{KH}_{2} \mathrm{PO}_{4}$ and $\mathrm{K}_{2} \mathrm{HPO}_{4}$ (to reduce $\mathrm{Na}^{+}$concentration in the non-salinised culture solution). Seedlings were transplanted on the seventh day into black-painted plastic containers (3 L capacity), filled with the same culture solution, each with 10 plants. Growth conditions were a $12 \mathrm{~h}$ light period of 400-500 $\mu \mathrm{mol} \mathrm{m} \mathrm{m}^{-2} \mathrm{~s}^{-1}$ (PAR) at $29-31^{\circ} \mathrm{C}$ and a dark period of $12 \mathrm{~h}$ at $26^{\circ} \mathrm{C}$. The black boxes containing rice seedlings were transferred to a greenhouse (with a temperature ranging from $20-35^{\circ} \mathrm{C}$ ) when the seedlings had three expanded leaves (there were 10 separate replications of one plant). The third leaves were chosen for analysis as they were the youngest fully expanded leaves together with the fact that the younger the rice seedling leaf the higher the transpiration rate (Yeo and Flowers, 1984). Then, plants were treated with the culture solution containing $\mathrm{NaCl}(50 \mathrm{mM})$ and PTS $\left(100 \mathrm{mg} \mathrm{L}^{-1}\right)$ for estimating bypass flow. Adult specimens of $P$. spumarius, collected from the field, were caged on the third leaves of both rice genotypes. The sampling (collection of the clear excreta fluid with a Hamilton syringe) started from the next day in two periods, during the morning (1000 h) and afternoon $(1700 \mathrm{~h})$, and continued for the next $4 \mathrm{~d}$. The sampling points were 19, 26, 41, 48, 63, 70, 85 and $92 \mathrm{~h}$ after initiation of salt stress. The macronutrient cations $\left(\mathrm{Na}^{+}, \mathrm{K}^{+}, \mathrm{NH}_{4}^{+}, \mathrm{Mg}^{2+}\right.$ and $\left.\mathrm{Ca}^{2+}\right)$ in meadow spittlebug excreta were determined by ion chromatography (Dionex). The excreta was analysed for PTS with a fluorescence spectrometer (Perkin-Elmer L-3). After sampling, the experimental leaves (the third) of all plants were excised and immediately weighed before extraction in $5 \mathrm{~mL}$ acetic acid at $90^{\circ} \mathrm{C}$ for $2 \mathrm{~h}$. Leaf extracts were analysed for $\mathrm{Na}^{+}$and $\mathrm{K}^{+}$concentrations using atomic absorption spectrometry. For the determination of transpiration rates, 10 individual plants (at the same age of plants in other experiments) of each genotype were put in black boiling tubes $(60 \mathrm{~mL})$ in normal or salinised (50 $\mathrm{mM} \mathrm{NaCl}$ ) culture solution. In addition, 10 other tubes without plants were used as blanks. Water loss was estimated by weighing the plants plus containers every day: the difference was considered as the water loss due to transpiration, since the change in plant weight was trivial in relation to water loss. The measurement of the transpired water was carried out over $8 \mathrm{~d}$ and the water lost from each tube was replaced every day.

Statistical tests used to evaluate significant differences were the $t$-test for $\mathrm{Na}^{+}, \mathrm{K}^{+}$, and $\mathrm{Mg}^{2+}$ concentrations $(P<0.05)$, and the Mann Whitney nonparametric test for $\mathrm{Ca}^{2+}, \mathrm{NH}_{4}^{+}$, and PTS. The nonparametric test was used since the concentrations of these three parameters did not follow a normal distribution.

\section{RESULTS}

The results of changes in cation concentrations $\left(\mathrm{Na}^{+}\right.$, $\mathrm{K}^{+}, \mathrm{Ca}^{2+}, \mathrm{Mg}^{2+}$ and $\mathrm{NH}_{4}^{+}$) and PTS over $4 \mathrm{~d}$ with eight sampling points are shown in Figure 1A-F. There was little or no change in the concentrations of $\mathrm{K}^{+}, \mathrm{Ca}^{2+}, \mathrm{Mg}^{2+}$ 

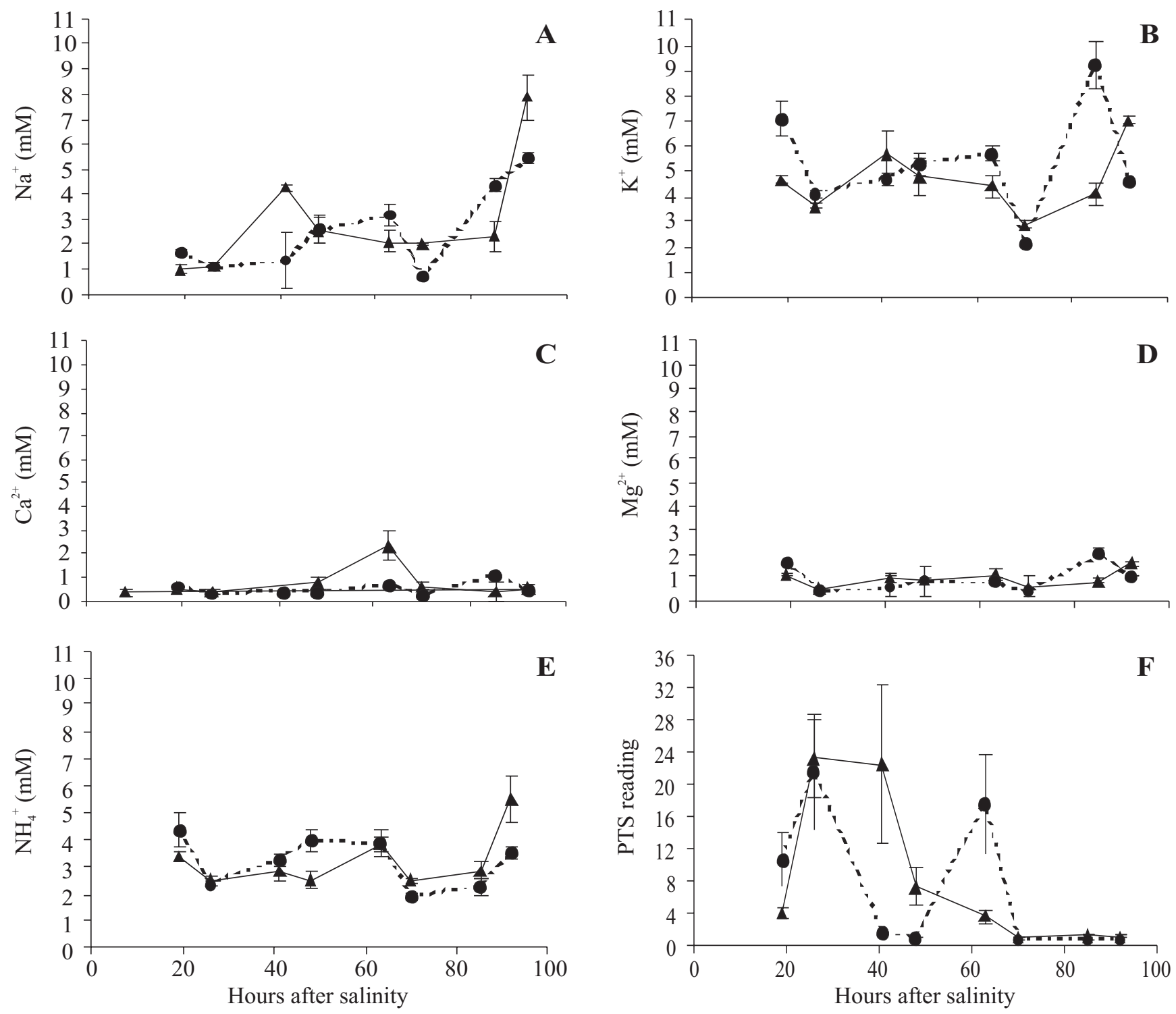

Figure 1. Concentrations of $\mathrm{Na}^{+}(\mathbf{A}), \mathrm{K}^{+}(\mathbf{B}), \mathrm{Ca}^{2+}(\mathbf{C}), \mathrm{Mg}^{2+}(\mathbf{D}), \mathrm{NH}_{4}^{+}(\mathbf{E})$, and PTS (F) in the xylem sap of the youngest expanded leaf (the third leaf) of (A) IR4630 and (•) IR15324 over $4 \mathrm{~d}$ and eight sampling points (19, 26, 41, 48, $63,70,85$ and $92 \mathrm{~h}$ ) after salinising the culture solution with $50 \mathrm{mM} \mathrm{NaCl}$. There was no significant change in the concentration of any cation and PTS ( $t$-test for $\mathrm{Na}^{+}, \mathrm{K}^{+}$, and $\mathrm{Mg}^{2+}-\mathrm{P}>0.05$; and Mann Whitney non-parametric test for $\mathrm{Ca}^{2+}, \mathrm{NH}_{4}^{+}$, and PTS ) in the xylem sap of the experimental leaves of either line over the harvesting period. $n=10 \pm$ SE.

or $\mathrm{NH}_{4}^{+}$(Figure 1B-E), over time. For $\mathrm{Na}^{+}$, statistical analysis (t-test analysis) indicated no significant differences between the cation concentrations of xylem sap in the two genotypes $(P>0.05)$ and mean concentrations were close (2.5 mM for IR4630 and $2.6 \mathrm{mM}$ for IR15324). The $\mathrm{Na}^{+}$and $\mathrm{K}^{+}$concentrations in the bulk of experimental leaves were also determined immediately after the final harvest. The results (Table 1) showed that the average $\mathrm{Na}^{+}$concentration of the third leaves of the

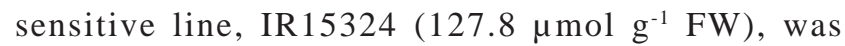
approximately 1.5 times that of the tolerant genotype, IR4630 (86.3 $\left.\mu \mathrm{mol} \mathrm{g}{ }^{-1} \mathrm{FW}\right)$. The average fresh weight of the third leaf for the sensitive line (52 mg) was greater than that of the tolerant line (44 mg), making it unlikely that any differences in ion concentration was due to differences in dilution by growth (the quantity of sodium for the sensitive line was about 1.8 times higher than that in the tolerant line: $6.7 \mu \mathrm{mol}$ per leaf in IR15324 and 3.8 
$\mu$ mol per leaf in IR4630). The difference between these two genotypes in sodium accumulation was even obvious when they were grown in normal culture solution (no salt stress), when the sodium concentration in the third leaves of IR15324 plants was 765 times that of IR4630 (30.6 $\mu \mathrm{mol} \mathrm{g}^{-1} \mathrm{FW}$ for IR15324 and $0.04 \mu \mathrm{mol} \mathrm{g}^{-1}$ FW for IR4630; Table 1). The average $\mathrm{K}^{+}$concentrations of the third leaves in both genotypes were similar (215 $\mu \mathrm{mol} \mathrm{g}{ }^{-1} \mathrm{FW}$ for the sensitive line and $219 \mu \mathrm{mol} \mathrm{g}^{-1} \mathrm{FW}$ for the tolerant line). Calculation of the quantity of $\mathrm{K}^{+}$in the third leaf of both lines showed approximate similarity (9.6 $\mu$ mol per leaf in IR4630 and $11.2 \mu$ mol per leaf in IR15324). Interestingly, $\mathrm{K}^{+}$concentration in the third leaves of control plants of both lines was similar to the values in stressed leaves (Table 1$)$. Calculation of $\mathrm{K}^{+} / \mathrm{Na}^{+}$selectivity $\left[\mathrm{S}_{\mathrm{K}, \mathrm{Na}}=\left(\mathrm{K}_{\text {plant }} / \mathrm{K}_{\text {medium }}\right) /\left(\mathrm{Na}_{\text {plant }} / \mathrm{Na}_{\text {medium }}\right)\right]$ from the $\mathrm{K}^{+}$and $\mathrm{Na}^{+}$concentrations in the third leaves showed that this value was greater in IR4630 than that in IR15324 (63 in IR4630 and 42 for IR15324; Table 2): the $\mathrm{K}^{+} / \mathrm{Na}^{+}$ratio was also higher (by 1.5 times) in IR4630 (2.5) than in IR15324 (1.7) (Table 2).

The results of estimating the PTS concentration in excreta samples showed no apparent difference between the PTS dye present in the xylem sap of the third leaves of IR4630 and IR15324 (Figure 1F); neither regression was significant (Mann-Whitney Test) and the mean concentrations were close (10.3 mM for IR4630 and 8.2 mM for IR15324).

Measurements of transpiration showed that not only in non-stressed plants, but also under salinity, the transpiration rates of these two lines were similar over $8 \mathrm{~d}$ of salinisation (Figure 2), although in the last two harvests the transpiration rate of IR4630 plants exceeded that of IR15324 which was due to the fact that the plant size differed under salinity (the plants of IR15324 line were greatly affected by salt).

\section{DISCUSSION}

The results obtained using PTS showed the presence of this material in the xylem sap of both lines but with similar concentrations: there was no evidence for a higher concentration of PTS in the sap of the sensitive line when compared to the resistant line. Since others (Yadav et al., 1996; Garcia et al., 1997) have shown a strong linear correlation between PTS and $\mathrm{Na}^{+}$in leaves, it might be predicted that $\mathrm{Na}^{+}$concentrations in the xylem sap of the two genotypes would be similar and this indeed was the case. The present results are not consistent with the hypothesis that a difference in salt tolerance in rice genotypes is a result of a difference in transpirational bypass flow (Yeo, 1992). The experimental measurements of transpiration rates also indicated that this parameter was similar for both lines under salinity; therefore it could not be claimed that a difference in transpiration rates brought about greater salt delivery into the sensitive than the tolerant line. The sodium concentration in the bulk leaf tissue of IR15324 was about twice that of IR4630, in spite of the fact that its concentration in the xylem sap of leaf 3 of the two genotypes was quite similar. There are two potential explanations for these facts: 1) the existence of different gradients of transpiration rates between leaves of these two genotypes, delivering differing quantities of $\mathrm{Na}^{+}$to individual leaves; and 2) the existence of $\mathrm{Na}^{+}$re-circulation via the phloem with different selectivity of membrane-bound transporters/ channels for $\mathrm{Na}^{+}$. The results of measurements of whole plant transpiration showed that this parameter was similar in both genotypes under salinity, so any explanation of a difference in delivery would have to involve differences between the genotypes in the effect of salinity on the transpiration rates of individual leaves - for example the sensitive line being unable to close its stomata so more water flowed through this leaf delivering more salt than in the tolerant line. The alternative

Table 1. Average $\mathrm{Na}^{+}$and $\mathrm{K}^{+}$concentrations in the bulk of the youngest (third) leaves and average leaf fresh weights of two rice lines on the fourth day after salt treatment ( 0 and $50 \mathrm{mM} \mathrm{NaCl}) . n=10 \pm \mathrm{SE}$.

\begin{tabular}{|c|c|c|c|c|c|}
\hline \multirow[t]{2}{*}{ Lines } & \multirow[t]{2}{*}{$\begin{array}{c}\text { Leaf FW } \\
\text { (mg) }\end{array}$} & \multicolumn{2}{|c|}{$\begin{array}{c}\mathrm{Na}^{+} \text {concentration } \\
\left(\mu \mathrm{mol} \mathrm{g}{ }^{-1} \mathrm{FW}\right)\end{array}$} & \multicolumn{2}{|c|}{$\begin{array}{c}\mathrm{K}^{+} \text {concentration } \\
\left(\mu \mathrm{mol} \mathrm{g} \mathrm{g}^{-1} \mathrm{FW}\right)\end{array}$} \\
\hline & & $0 \mathrm{mM}$ & $50 \mathrm{mM}$ & $0 \mathrm{mM}$ & $50 \mathrm{mM}$ \\
\hline IR4630 & $44 \pm 3$ & $0.04 \pm 0.001$ & $86.3 \pm 27.3$ & $212.7 \pm 7.8$ & $218.7 \pm 18.3$ \\
\hline IR15324 & $52 \pm 6$ & $30.60 \pm 0.900$ & $127.8 \pm 40.8$ & $193.5 \pm 2.9$ & $214.5 \pm 26.5$ \\
\hline
\end{tabular}


Table 2. $\mathrm{K}^{+} / \mathrm{Na}^{+}$ratio and $\mathrm{K}^{+} / \mathrm{Na}^{+}$selectivity $\left[\mathrm{S}_{\mathrm{K}, \mathrm{Na}}=(\mathrm{K}\right.$ plant $\left.\left./ \mathrm{K}_{\text {medium }}\right) /\left(\mathrm{Na}{ }_{\text {plant }} / \mathrm{Na}{ }_{\text {medium }}\right)\right]$ in the third leaves of two rice lines on the fourth day after salt treatment $(50 \mathrm{mM}$ $\mathrm{NaCl}) . n=10 \pm \mathrm{SE}$.

\begin{tabular}{lcc}
\hline Lines & $\mathrm{K}^{+} / \mathrm{Na}^{+}$ratio & $\mathrm{K}^{+} / \mathrm{Na}^{+}$selectivity \\
\hline IR4630 & $2.5 \pm 2.2$ & $63 \pm 0.6$ \\
IR15324 & $1.7 \pm 0.2$ & $42 \pm 1.2$ \\
\hline
\end{tabular}

explanation of a difference in sodium retranslocation via the phloem may also be the cause of the higher $\mathrm{Na}^{+}$ concentration in the blades of the third leaves of IR15342 than IR4630. A remarkable difference was also found between the lines in $\mathrm{Na}^{+}$accumulation when they grew in un-salinised culture solution: the third leaves of IR15324 plants had 765 times the $\mathrm{Na}^{+}$concentration seen in the leaves of IR4630 (Table 1). Although the normal culture solution for rice (Yoshida et al., 1976) has no $\mathrm{Na}^{+}$added as a macro- or micronutrient, there was still a trace of this element from the iron supplement $\left\{\left[\mathrm{CH}_{2} \cdot \mathrm{N}\left(\mathrm{CH}_{2} \cdot \mathrm{COO}\right)_{2}\right] 2\right.$ FeNa; $36 \mu \mathrm{M}$ \} in the culture solution. This difference in plant $\mathrm{Na}^{+}$at low external concentration suggests that there is a difference in $S_{\mathrm{Na}, \mathrm{K}}$ between the genotypes, perhaps signifying a difference in the selectivity of $\mathrm{K}^{+}$ transporters. It is possible to grasp a hint of differences in the selectivity of transporters and channels between IR15324 and IR4630 from estimates of $\mathrm{Na}^{+} / \mathrm{K}^{+}$selectivity in the third leaves (63 for IR4630 and 42 for IR15324; Table 2 ) as well as that in the whole plants of both lines (17.5 for IR4630 and 12.9 for IR15324), taking into account the values of $\mathrm{Na}^{+}$influx $\left(1264 \mu \mathrm{mol} \mathrm{g}{ }^{-1}\right.$ root DW d ${ }^{-1}$ for IR4630 and $1747 \mu \mathrm{mol} \mathrm{g}^{-1}$ root DW d ${ }^{-1}$ for IR15324) (unpublished data). The $\mathrm{K}^{+} / \mathrm{Na}^{+}$selectivity in the individual leaf and in the whole plant of IR4630 was greater than in IR15324 and the value of $\mathrm{Na}^{+}$influx was higher in the roots of IR15324 than that in IR4630. It is known that OsHKT1 mediates $\mathrm{Na}^{+} / \mathrm{K}^{+}$transport (Golldack et al., 2003; Horie et al, 2007). If $\mathrm{Na}^{+}$does enter rice through OsHKT1, which is expressed in the root epidermis and root and leaf vasculature (Golldack et al., 2003), then the considerable difference in $\mathrm{Na}^{+}$uptake from low external $\mathrm{Na}^{+}$between IR4630 and IR15324 may reflect a difference in the properties or expression of this protein between the two genotypes. It is possible that $\mathrm{Na}^{+}$enters the phloem of the sensitive line and is transported to developing leaves by this route. If the properties of the root epidermal and phloem proteins were similar, it would be expected that
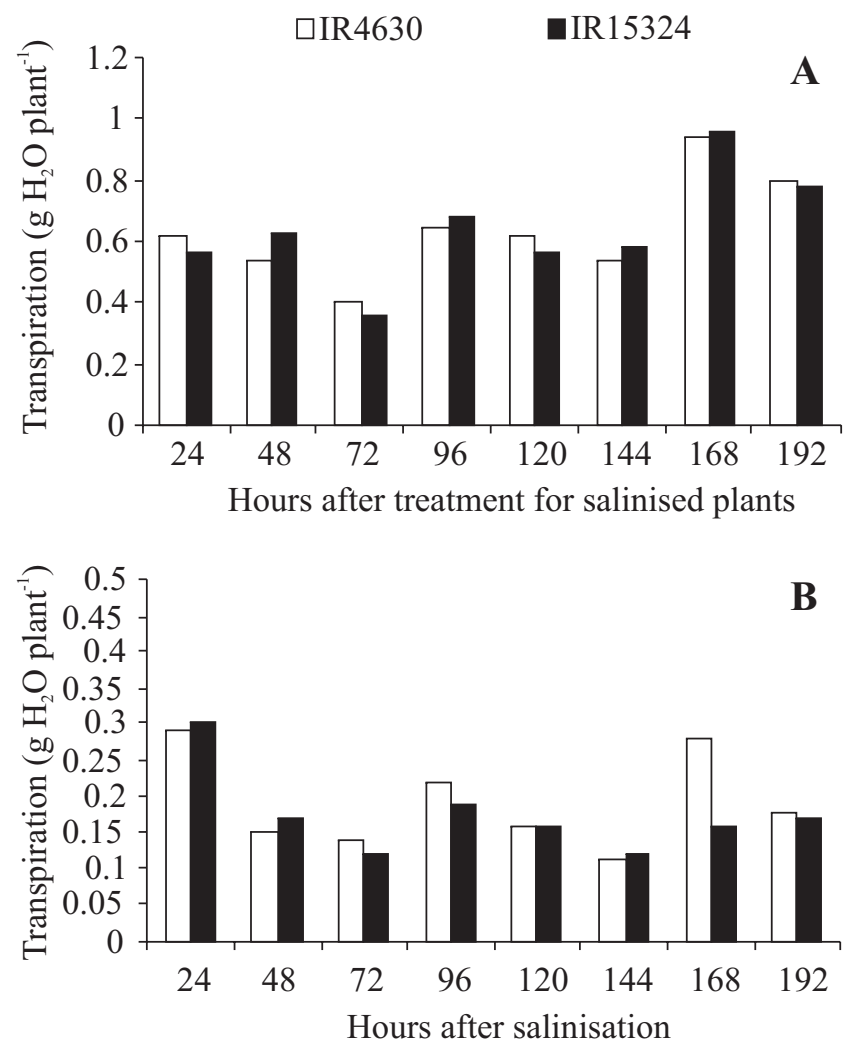

Figure 2. Comparison of transpiration rates $\left(\mathrm{g} \mathrm{plant}^{-1}\right)$ of two rice lines, IR4630 and IR15324, over the $8 \mathrm{~d}$ experimental period. Measurements began $24 \mathrm{~h}$ after adding salt ( $50 \mathrm{mM} \mathrm{NaCl}$ ) to the medium, when plants were 12-dold. The number of plants of both genotypes in both treatments was ten, except for the last two time points of salinisation, where plant number was reduced to six for IR15324 (the sensitive line). (A) control plants, (B) salttreated plants.

more $\mathrm{Na}^{+}$would enter the phloem of IR15324 than of IR4630. Berthomieu and Conejero (2003) and some others (Mäser et al., 2002; Sunarpi et al., 2005) pointed out that AtHKT1 in Arabidopsis thaliana plays a role in sodium recirculation by loading $\mathrm{Na}^{+}$into the phloem sap in shoots and unloading in the roots; maybe OsHKT1 has the same role in rice plants. It is, however, difficult to see the functional value attributed by Berthomieu and Conejero (2003) to such recirculation, which simply delivers $\mathrm{Na}^{+}$for further recycling. Sodium is safest locked away in leaf cell vacuoles.

Concentrations of the other cations $\left(\mathrm{K}^{+}, \mathrm{Ca}^{2+}, \mathrm{Mg}^{2+}\right.$ and $\mathrm{NH}_{4}^{+}$) in the xylem sap of both lines did not differ significantly, suggesting that despite the more sensitive nature of IR15324 to salinity (in comparison to IR4630) 
the delivery of these cations to the xylem was similar and was unaffected by salt, implying that even sensitive rice genotypes are able to maintain their cation transport capability, at least in the early stages after the onset of salinity. The similarity of $\mathrm{K}^{+}$concentrations in the xylem sap of both lines was consistent with the similarity of its concentrations in the bulk tissue of the same leaves. The similarity of $\mathrm{K}^{+}$concentration in the xylem sap of leaves of two wheat genotypes with different sensitivity to salt has already reported by Watson et al. (2001). Interestingly, $\mathrm{K}^{+}$concentration in the third leaves of control plants of both lines was similar to the values in stressed leaves. These results are consistent with the findings of Golldack et al. (2003). They reported that IR29 (a salt-sensitive line of rice), Pokkali and BK (saltresistant lines) were able to maintain $\mathrm{K}^{+}$levels under 150 $\mathrm{mM} \mathrm{NaCl}$, while the $\mathrm{Na}^{+}$concentrations in the leaves of IR29 increased 10-fold relative to the $\mathrm{Na}^{+}$concentration in BK or Pokkali. The concentration of $\mathrm{Na}^{+}$and $\mathrm{K}^{+}$in plants previously grown in a solution dominated by $\mathrm{K}^{+}$with very low $\mathrm{Na}^{+}$and then given a short exposure to $\mathrm{Na}^{+}$ largely reflects the conditions of early growth. Nevertheless, it is possible that IR15324 plants obtained $\mathrm{K}^{+}$retranslocated in the plants to supply the necessary concentration of $\mathrm{K}^{+}$for young leaves; a high efficiency in $\mathrm{K}$ utilisation within the plant has been proposed to be an important factor in combating salinity impacts in plants.

Acknowledgments: I would like to thank Professor Tim Flowers, Dr. Mike Malone and Dr. Rachael Bridges for their help. These experiments were supported by a scholarship from the Ministry of Sciences, Research and Biotechnology of Iran and conducted at the School of Life Sciences of the University of Sussex, Brighton, UK.

\section{REFERENCES}

Amtmann A, Sanders D (1999) Mechanisms of $\mathrm{Na}^{+}$uptake by plant cells. Adv. Bot. Res. 29:75-112.

Apse MP, Blumwald E (2007) $\mathrm{Na}^{+}$transport in plants. FEBS Lett. 581:2247-2254.

Berthomieu P, Conejero G (2003) Functional analysis of AtHKT1 in Arabidopsis shows that $\mathrm{Na}^{+}$recirculation by the phloem is crucial for salt tolerance. Embo J. 22:2004-2014.

Blumwald E, Aharone GS, Apse MP (2000) Sodium transport in plant cells. Biochim. Biophys. Acta
1465:140-151.

Flowers TJ, Yeo AR (1995) Breeding for salinity resistance in crop plants: where next? Aust. J. Plant Physiol. 22:875-884.

Garcia A, Rizzo CA, Ud-din J, Bartos SL, Senadhira D, Flowers TJ, Yeo AR (1997) Sodium and potassium transport to the xylem are inherited independently in rice, and the mechanism of sodium: potassium selectivity differs between rice and wheat. Plant Cell Environ. 20:1167-1174.

Golldack D, Quigley F, Michalowski CHB, Kamasani UR, Bohnert HJ (2003) Salinity stress-tolerant and sensitive rice (Oryza sativa L.) regulate AKT1-type potassium channel transcripts differently. Plant Mol. Biol. 51:71-81.

Gong HJ, Randall DP, Flowers TJ (2006) Silicon deposition in the root reduces sodium uptake in rice (Oryza sativa L.) seedlings by reducing bypass flow. Plant Cell Environ. 29:1970-1979.

Hasegawa PM, Bressan AB, Zhu JK, Bohnert HJ (2000) Plant cellular and molecular responses to high salinity. Annu. Rev. Plant Physiol. Plant Mol. Biol. 51:463-499.

Horie K, Costa A, Kim HT, Han MJ, Horie R, Leung H, Miyao A, Hirochika H, An G, Schroeder JS (2007) Rice OsHKT2;1 transporter mediates large $\mathrm{Na}^{+}$influx component into $\mathrm{K}^{+}$-starved roots for growth. EMBO J. 26:3003-3014.

Lessani H, Marschner H (1978) Relation between salt tolerance and long-distance transport of sodium and chloride in various crop species. Aust. J. Plant Physiol. 5:27-37.

Maathuis FJM, Sanders D (2001) Sodium uptake in arabidopsis roots is regulated by cyclic nucleotides. Plant Physiol. 127:1617-1625.

Malone M, Herron M, Morales MA (2002) Continuous measurements of macronutrient ions in the transpiration stream of intact plants using the meadow spittlebug coupled with ion chromatography. Plant Physiol. 130:1436-1442.

Malone M, Watson R, Pritchard J (1999) The spittlebug Philaenus spumarius feeds from mature xylem at the full hydraulic tension of the transpiration stream. New Phytol. 143:261-271.

Mäser P, Gierth M, Schroeder J (2002) Molecular mechanisms of potassium and sodium uptake in plants. Plant Soil 247:43-54. 
Munns R (2002) Comparative physiology of salt and water stress. Plant Cell Environ. 25:239-250.

Munns R, Husain S, Rivelli AR, James RA, Condon AG, Lindsay MP, Lagudah ES, Schachtman DP, Hare RA (2002) Avenues for increasing salt tolerance of crops, and the role of physiologically based selection traits. Plant Soil 247:93-105.

Sunarpi, Horie T, Motoda J, Kubo M, Yang H, Yoda K, Horie R, Chan W Y, Leung H Y, Hattori K, Konomi M, Osumi M, Yamagami M, Schroeder JI, Uozumi N (2005) Enhanced salt tolerance mediated by AtHKT1 transporter induced $\mathrm{Na}^{+}$unloading from xylem vessels to xylem parenchyma cells. Plant J. 44:928-938.

Tester M, Davenport R (2003) $\mathrm{Na}^{+}$tolerance and $\mathrm{Na}^{+}$ transport in higher plants. Ann. Bot. 91:503-527.

Watson R, Pritchard J, Malone M (2001) Direct measurement of sodium and potassium in the transpiration stream of salt-excluding and nonexcluding varieties of wheat. J. Exp. Bot. 52:1873-1881.
Yadav R, Flowers TJ, Yeo AT (1996) The involvement of the transpirational bypass flow in sodium uptake by high- and low-sodium-transporting lines of rice developed through intravarietal selection. Plant Cell Environ. 19:329-336.

Yeo AR (1992) Variation and inheritance of sodium transport in rice. Plant Soil 146:109-116.

Yeo AR, Flowers TJ (1984) Mechanisms of salinity resistance in rice and their role as physiological criteria in plant breeding. In: Staples RC, Toenniessen GA (eds), Salinity Tolerance in Plants: Strategies for Crop Improvement, pp.151-170. Wiley, New York.

Yeo AR, Yeo ME, Flowers TJ (1987) The contribution of an apoplastic pathway to sodium uptake by rice roots in saline conditions. J. Exp. Bot. 38:1141-1153.

Yoshida S, Forno DA, Cock JH, Gomez KA (1976) Laboratory Manual for Physiological Studies of Rice, $3^{\text {rd }}$ ed. The International Rice Research Institute, Manila. 